\title{
Finance in Family Business Studies: A Systematic Literature Review
}

\author{
Carmen Gallucci ${ }^{1}$, Rosalia Santulli ${ }^{1} \&$ Michela De Rosa ${ }^{1}$ \\ ${ }^{1}$ Department of Management and Innovation Systems, University of Salerno, Fisciano (SA), Italy \\ Correspondence: Carmen Gallucci, Department of Management and Innovation Systems, University of Salerno, Via \\ Giovanni Paolo II, 132, Fisciano (SA), Italy. Tel: 39-089-963-436.
}

Received: May 23, 2017

Accepted: June 19, 2017

Online Published: July 9, 2017

doi:10.5430/ijba.v8n5p11

URL: https://doi.org/10.5430/ijba.v8n5p11

\begin{abstract}
The aim of this paper is to examine how the family business literature and financial issues interact. It is carried out on 448 articles methodically selected from 24 management journals and 102 finance journals. After discussing the periodical development of literature, the study identifies the key research topics in the both fields and by crossing the results it identifies specific interaction trends. The classical financial theory cannot be applied to family businesses. The outcome of this research discloses that socioemotional wealth could contribute to determine a new perspective under which to examine the interplay between the family and the business. The schematic overview on the state of art let us reflect on the gaps that could be bridged, through a coherent advancing of financial studies in family business. The understanding that classical financial theory cannot be applied to family businesses and the discovery of peculiar family business dynamics can assure the continuity of the firm by defying the growth of firm's value in term of the emotional components beyond the financial considerations. This review shows to researchers a wider scenario of the family business by leading to many challenges and gives an essential support to scholars in advancing a beneficial research.
\end{abstract}

Keywords: systematic literature review, financial issues, socio-emotional wealth

\section{Introduction}

As Voordeckers, Le Breton-Miller, Miller, Jain, \& Shao (2014) stated, in the last 5 years, there has been a significant increasing interest about financial issues in family business studies (Voordeckers, Le Breton-Miller, Miller, Jain, \& Shao, 2014). Typical financial issues applied to the family business assume a different profile because of the interaction between two systems, the family and the business (Basco \& Pérez Rodríguez, 2009; Habbershon, Williams, \& MacMillan, 2003; Hollander \& Elman, 1988; Swartz, 1989). For example, the investigation of the business performance should not be limited to the consideration of a quantitative analysis, but ought to focus on the family health beyond the business success (Olson et al., 2003; Stafford, Duncan, Danes, \& Winter, 1999). Again, traditional corporate finance's theoretical frameworks (i.e, agency theory) find a specific application in family business field (Schulze, Lubatkin, \& Dino, 2003; Corbetta \& Salvato 2004; Chua, Chrisman, \& Bergiel, 2009). In addition, financial challenges play an essential role as the business grows; from the family members' perspective, the business must provide security and comfort and divergences emerge among active and passive shareholders (Anderson \& Reeb 2003; Morck, Shleifer, \& Vishny, 1988; Allouche, Amann, Jaussaud, \& Kurashina, 2008), from the business perspective, it needs to consider the satisfaction of financial investments in view of better performance. These insights highlight the role of governance mechanisms as provider of family stability and business success (Steier 2001; Mustakallio, Autio, \& Zahra, 2002; Brenes, Madrigal, \& Requena, 2011). Moreover, by examining the responses of family companies with respect to mergers and acquisition activities, it emerges how the family perspective influences the approach of a family firm to the prospect of merger or takeover (Steen \& Welch 2006; Franks, Mayer, Volpin, \& Wagner, 2011). The family perspective is a critical driver for strategical choices and the entrepreneurial activities is conditioned through its values and aspirations, as though takeover could implicate changes on the profile of family involvement and influence. In this challenge, financial and emotional dynamics are implicated. Specifically, from the acquirers' perspective, they should not ignore the family perspective in takeovers of family firms (Gisser \& Gonzalez, 1993) in fact, the family determination is to retain the control and a merger or sale of a family business does not necessarily mean the end of family involvement and influence. To maintain affective value - such as status and reputation in the community, influence, and pride - families are keen on ensuring their ongoing control of their firms (Gomez-Mejía, Cruz, Berrone, \& De Castro, 2011). The choice to accept the 
selling option could seem the long-awaited opportunity to make progress, because it is synonymous of a comfortable financial position, almost when the founder is approaching to the retirement age, but it needs to consider the consequences on the new generation's future careers. The decision concerning the selling of the family owed company has implications for the succession plan of the founder with consequences for the news generations careers and ambitions. Financial considerations are not always compatible with emotional considerations, and it is important to find the right balance among them. Therefore, family business represents an interesting field in which investigate financial issues. Nevertheless, to date, the contributions on these issues are poor (among others, Astrachan, \& Shanker, 2003; Miller \& Le Breton-Miller, 2006; Zahra, 2005; Dyer, 2006) and there is a call for more research. With the aim to provide a guideline for both family business and financial scholars, this paper presents a systematic literature review process (Tranfield, Denyer, \& Smart 2003). The study proposes an analysis of the state of academic research on finance in family business by synthesizing various research perspectives into a comprehensive schematic overview. The selection process observes 24 management journals and 102 finance journals, identifying 448 relevant articles. The distinct investigation in the two subject areas (finance and management) catches the different approaches followed by different typologies of scholars, to establish connections and to identify gaps. Concerning the family business themes, the more significant are the governance, the succession and the family involvement. As for the financial topics, the firm's performance, the firm's value and the financial structure found out. One of the main disparity about the issues discussed concerns the lacking investigation in the financial field of the socioemotional wealth (Berrone, Cruz, Gomez-Mejia, \& Larraza-Kintana, 2010; Gomez-Mejia et al., 2011; Gomez-Mejia, Haynes, Núñez-Nickel, Jacobson, \& Moyano-Fuentes, 2007), which is diffusely investigated by management authors. The socioemotional wealth could be a useful lens to interpret financial issues and contribute to create a more integrated vision of the common ground shared by family business and financial disciplines. The integration of emotional contents in the financial research could be an effective path to follow to understand family business through a more coherent financial perspective. Possible directions for future research will be discussed in the next paragraphs, hopefully to provide an effective support to family business and finance scholars, actively contributing to improve the growing body of financial and family business literature.

\section{Method}

This paper presents a systematic literature review (Tranfield et al., 2003) to realize a consistent study that investigates the state of art of financial research in family business field and vice versa. This methodology, by adopting a replicable, scientific and transparent process, allow to identifies key scientific contributions to financial implications in family business (Tranfield et al., 2003). The goal in this review is a conceptual consolidation of the fragmented financial and management fields in order to support academics with different background in advancing a research coherent with the real operational needs and practical implications. This fact, justifies the adoption of a descriptive rather than statistical method.

This research adopted the three-stage procedure: planning, conducting, and reporting (Tranfield et al., 2003). In the first stage, it defined the objectives of the research and identified the key data source. In order to assess publications for this review, it focused on both the management and the financial journals. Specifically, it considered the 22 journals mentioned by Chrisman, Chua, Kellermanns, Matherne III, \& Debicki's work (2008) (Chrisman, Chua, Kellermanns, Matherne III, \& Debicki, 2008). The adoption of this reference recognize a ranking of management journals as outlets for family business research. To this list, "Journal of Family Business Strategy" and "Journal of Family Business Management" were added. As regard the financial journals sample (FJS), the reference is the JQL published in 2015 taking into account 102 journals in the finance/accounting subject area.

The conducting stage of the review was composed by four steps:

1. Identifying articles on financial issues in family firms

2. Excluding articles not written in English language;

3. Reading and analysing by each author in order to pick pertinent articles that address to "Family Business and Finance";

4. Synthesis of results.

After this screen process, the research pointed out a sample of 5143 articles. Next, eliminating the duplications, 3747 articles composed the sample, 448 were relevant: 157 from management literature and 291 from financial literature. Tables 1 and 2 show the results of this selection respectively for management journals and financial journals. 
Table 1. Selection process for finance journals (JQL)

\section{Financial Journals Sample}

After keyword search in the title and/or abstract and/or keywords

$\begin{array}{ccccc}\text { A+/A } & \text { B } & \text { C } & \text { D } & \text { TOTAL } \\ 448 & 649 & 339 & 526 & \mathbf{1 9 6 2} \\ 342 & 468 & 261 & 462 & \mathbf{1 5 3 3} \\ 75 & \mathbf{9 2} & \mathbf{5 2} & \mathbf{3 5} & \mathbf{2 5 4}\end{array}$

After deleting duplicates

$75+92-52-35$

After evaluating the relevance

\begin{tabular}{|c|c|c|c|c|c|c|c|}
\hline $\begin{array}{l}\text { Ess } \\
0+-3\end{array}$ & 2015 & $\begin{array}{r}\text { ABS } \\
4\end{array}$ & $\begin{array}{l}2015 \\
-1\end{array}$ & $\begin{array}{r}\text { Abdc } \\
\mathbf{A}^{*}\end{array}$ & $\begin{array}{l}2013 \\
C\end{array}$ & $\begin{array}{l}\text { Den } \\
2-1\end{array}$ & 2011 TOTAL \\
\hline 2 & 1 & 3 & 2 & $\mathbf{A} * / \mathbf{A}$ & C & 2 & \\
\hline 37 & 117 & 5 & 33 & 186 & 3 & 256 & 637 \\
\hline 30 & 93 & 4 & 23 & 171 & 3 & 229 & 553 \\
\hline 19 & 1 & 0 & 14 & 3 & 0 & $\mathbf{0}$ & 37 \\
\hline
\end{tabular}

After keyword search in the title and/or abstract and/or keywords

After deleting duplicates

After evaluating the relevance

Final sample size $254+37=291$

Table 2. Selection process for management journals

\section{Management Journals Sample}

No Articles

After keyword search in the title and/or abstract and/or keywords

After deleting duplicates

After evaluating the relevance

Articles in Family Business Review

Articles in Journal of Family Business Management

Articles in Journal of Family Business Strategy

For the synthesis of results, this study considered the number of citations received for each articles and the publication date by focusing on the most recent articles.

\section{Results}

This section provides a descriptive analysis of samples. Following it shows a schematic overview on the family business and financial topics identified. At the end, it argues the theoretical framework emerging from the both research domains. 


\subsection{Descriptive Analysis}

The selected articles date back from the 60' so far. The first sign of the topic emerges from the financial literature in 1967 with a discussion about stakeholder agreement in the family-held corporation (Milston \& Cohn; 1967). In the management journal sample (MJS), the first article was published in 1990 in "Family Business Review" and it addressed to financing of family firms (Dreux; 1990). Looking at the general trend, it is evident that the financial scholars' contribution in family business studies is more significant. An inverted trend is registered only in few years. In the FJS, there are traces of the questioned topic also during the period between the 60' and the $90^{\prime}$ 'but the research followed an irregular trend. On the contrary, an essential contribution from the management literature come to light starting from $90^{\prime}$. During these years, the debate concerns both fields but the financial domain rules the management one, even if in 1996 there is a major output from the latter. In both fields, a huge amount of publications is realized from 2000 so far, the increasing trend is initially moderate, between 2008 and 2010 a real decrease emerges, but in the last five years the development becomes crucial.

Table 3. Periodical distribution of articles published in management and finance journals

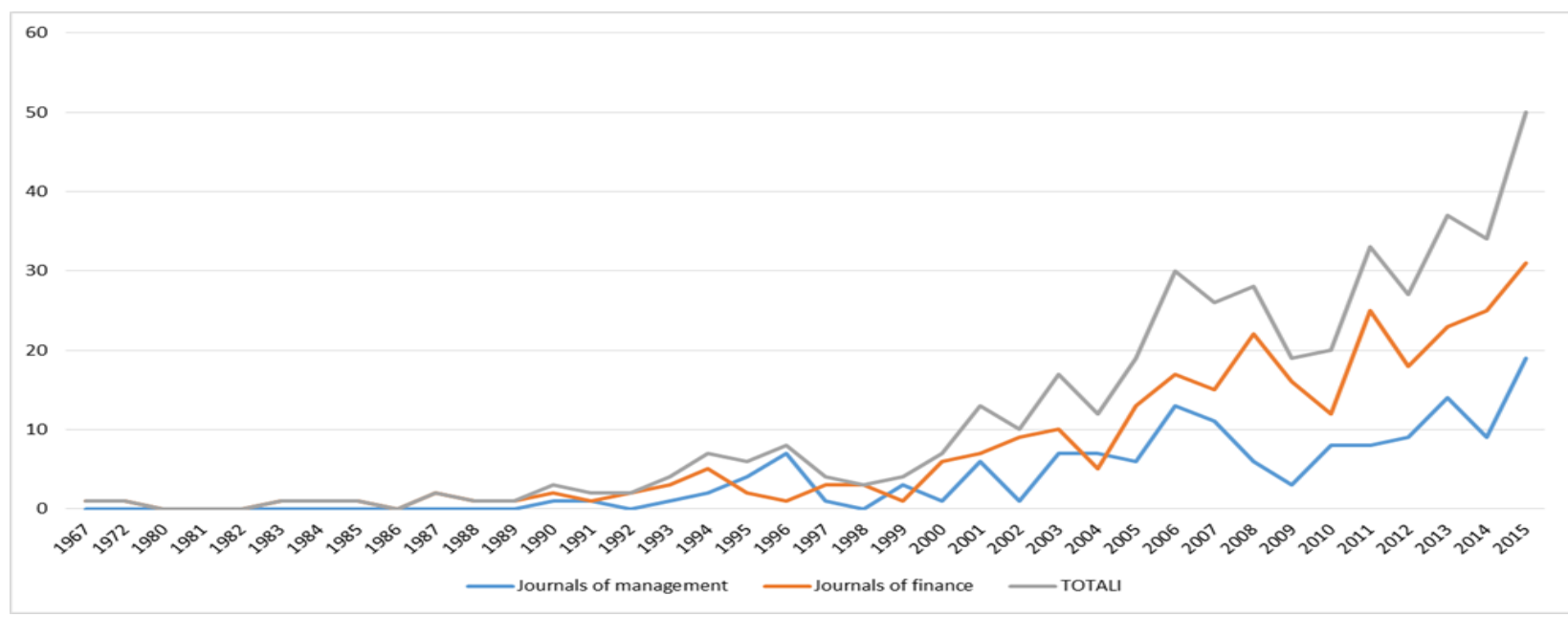

Examining in depth the periodical distribution of publications, interesting results surface. In particular, an inverted trend emerges by considering the rating of journals. In the MJS a prevalence of articles published in the journals with rating $\mathrm{B}$ emerges until the 2010 , but in the maturity stage, journals with rating $\mathrm{A} / \mathrm{A}+$ are more productive. The FJS follow a different evolution, because the journals with rating $\mathrm{B}$ result to be more active in the family business research since 2005. As for the previous period, an irregular trend emerges, with a prevalence of journals with rating D in 90' and with rating A/A+ since 2000 even if the evolution is more moderate. In contrast with the trend registered for the MS sample, the financial research is sufficiently proactive also considering journals with rating $\mathrm{C}$, almost since 2005 . 
Table 4. Periodical distribution journals of management

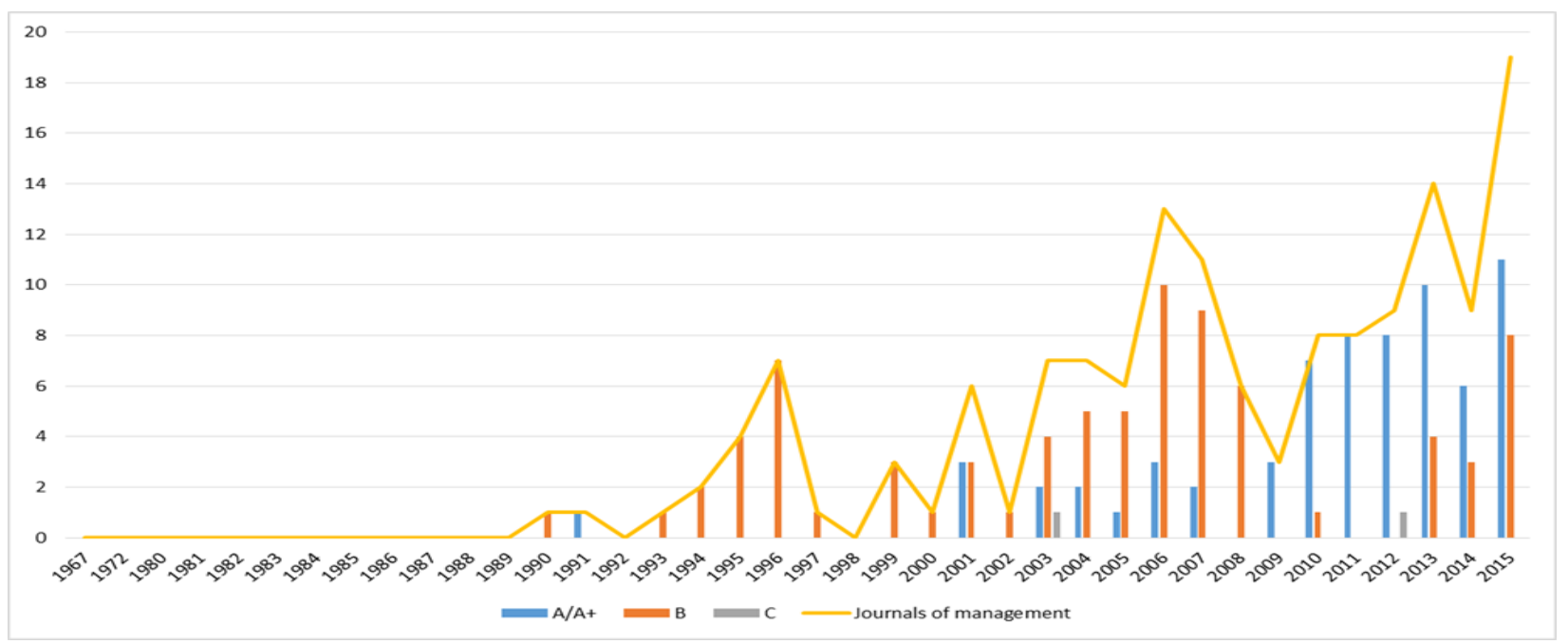

Table 5. Periodical distribution journals of finance

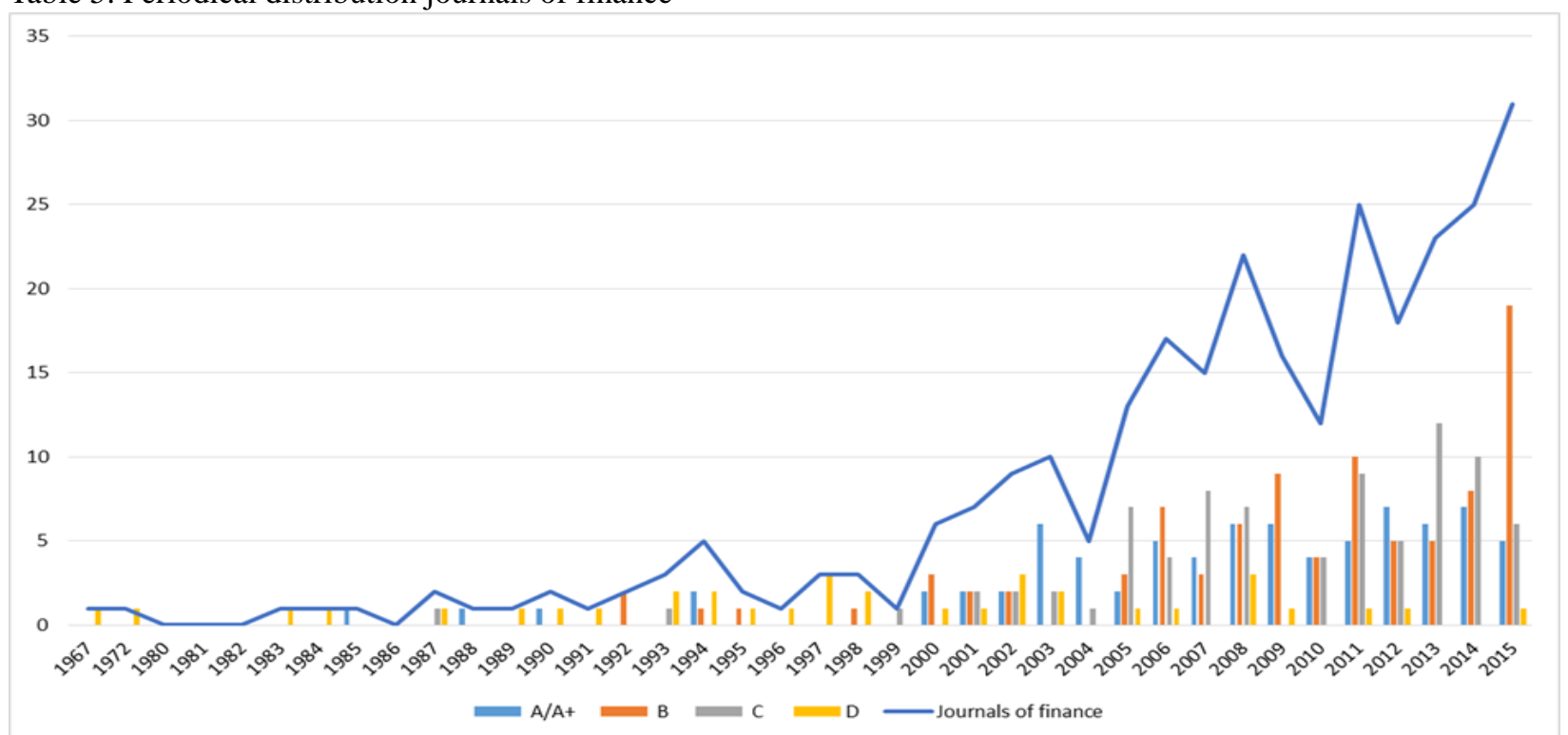

Checking for the country of analysis in management journals, a considerable amount of studies refers to south Europe, as Spain or Italy (Arosa, Iturralde, \& Maseda, 2010; Mazzola, Sciascia, \& Kellermanns, 2013). The remaining has a heterogeneous distribution focusing on North Europe countries, France (Mahérault, 2004), Belgium (Praet, 2013), Germany (Koropp, Grichnik, \& Kellermanns, 2013), Austria, East Europe, West Asia, North and South America (Dreux, 1990), scarce attention is paid to a multi-country context. Concerning the financial field, different results emerge: the most explored area is Asia especially Japan and China; the multi country context is frequently investigated as much as America particularly U.S.; in Europe, continental countries are predominant, followed by the Northern and the Southern side with less relevance. Furthermore, considering the dimension of family firms investigated, authors with a managerial background focus their research on SMEs belonging to the private sector. Otherwise, financial studies are polarised on larger companies, especially in the public sector and listed on Stock Exchange. In the matter of the methodological approaches, in both samples the use of quantitative analysis is prevailing, coherently with the substantial presence of empirical studies, an irrelevant percentage of studies using a qualitative approach found out, especially in the financial domain. Authors often use both qualitative and quantitative analysis in order to discuss the theoretical framework supporting the model based on the assumption adopted. To 
define a business as familiar, the authors have adopted those, which are in line with the perspective implemented in the specific studies. There are distinct methods for the identification of family involvement, but the majority take into account the ownership as scale of measure (Among others; Di Giuli, Caselli, \& Gatti, 2011; Porta, Lopez-de-Sinales, \& Shleifer, 1999; Claessens, Djankov, \& Lang, 2000). In this case, the percentage of stock owned by family members is synonymous of their commitment. Others studies examine the family involvement in management, as the number of family members taking part in the management team (Among others, Kim, \& Gao, 2013). The choice to considerate ownership and management as lens to examine the family involvement depends on the needs to be the most possible objective in the definition and to focus on the specific correlation between the presence of the family in the business and the essential financial variables investigated. In spite of the approach followed, this study focuses on the measures discussed in the publications without the adoption of any filter for the definition of family business in order not to limit our analysis considering the conditioning by the theoretical lens and the methodological approach.

\subsection{Family Dimensions and Finance Dimensions}

The analysis proceeded by identifying the most recurrent family and financial dimensions. As for the dimensions used to characterize family business, the research produced a heterogeneous scenario due to the huge amount of articles selected.

Table 6. Family dimensions

\begin{tabular}{|c|c|c|}
\hline $\begin{array}{l}\text { Family } \\
\text { dimensions }\end{array}$ & Financial journals sample & Management journals sample \\
\hline $\begin{array}{l}\text { Family } \\
\text { involvement in } \\
\text { governance }\end{array}$ & \multicolumn{2}{|c|}{ Family Ownership, Family Management } \\
\hline $\begin{array}{l}\text { Family } \\
\text { involvement in } \\
\text { ownership }\end{array}$ & Family non-family shareholders & $\begin{array}{l}\text { Family influence, family and non-family } \\
\text { shareholders }\end{array}$ \\
\hline $\begin{array}{l}\text { Family } \\
\text { involvement in } \\
\text { board }\end{array}$ & \multicolumn{2}{|c|}{ Family members in control positions } \\
\hline $\begin{array}{l}\text { Family } \\
\text { involvement in } \\
\text { management }\end{array}$ & \multicolumn{2}{|c|}{ Family management } \\
\hline Succession & \multicolumn{2}{|c|}{$\begin{array}{l}\text { Process, developed in consecutive phases through which family members realize the transfer of } \\
\text { the business from the older to the younger generation }\end{array}$} \\
\hline $\begin{array}{l}\text { Firm's } \\
\text { characteristics } \\
\text { Family }\end{array}$ & \multirow{2}{*}{\multicolumn{2}{|c|}{ Firm's age, firm's size }} \\
\hline $\begin{array}{l}\text { business } \\
\text { group }\end{array}$ & & \\
\hline Networks & $\begin{array}{c}\text { Family relationship, Non-family relationship, } \\
\text { Interpersonal trusts, Convergence of interests, } \\
\text { Shareholders-debtholders relationships, } \\
\text { Political environment, Family limited } \\
\text { partnership }\end{array}$ & $\begin{array}{l}\text { Family relationships, Non-family relationships, } \\
\text { Trust among team work, Political Environment }\end{array}$ \\
\hline Culture & $\begin{array}{l}\text { Corporate culture, Social culture, Family } \\
\text { culture, Marriage, Religion, Socioemotional } \\
\text { wealth, Family structure }\end{array}$ & $\begin{array}{l}\text { Marriage, Divorce, Socioemotional wealth, } \\
\text { Family structure }\end{array}$ \\
\hline Corporate & & \\
\hline $\begin{array}{l}\text { Social } \\
\text { Responsibility }\end{array}$ & Family foundations & \\
\hline Family capital & & Human capital, Social capital \\
\hline
\end{tabular}


Depending on the literature background, the purpose of different dimensions changes, as for their level of repetition and the theory applied to explain the interaction among the variables investigated. Each dimension has a different degree of detail, some of them give a contribution to specify what a family business is, and referring to the unique dynamics characterizing family business, others are less odd. Among the selected articles, we observed some dimensions present in both journals samples. Making a comparison among the common areas, we can find out a scarce level of contrast. Table 7 shows the most relevant themes.

Table 7. Number of articles for each family dimension in finance and management journals

\begin{tabular}{lcc}
\hline Themes & $\begin{array}{c}\text { Financial Journals Sample } \\
\text { No. Articles }\end{array}$ & $\begin{array}{c}\text { Management Journals Sample } \\
\text { No. Articles }\end{array}$ \\
\hline Family involvement in ownership & 103 & 19 \\
Family involvement in governance & 81 & 27 \\
Succession & 36 & 16 \\
Family involvement in board & 21 & 7 \\
Family involvement in management & 8 & 15 \\
\hline
\end{tabular}

Among the management publications, the most debated issue is the ownership. In particular, many authors focus on the family presence in board, as synonymous of family's capability to maintain the control over the firm. As consequence, succession process appears among the most debated themes, because it is often linked with the family's will to maintain and improve the family influence, through a direct commitment in the business. Moreover, while from the management field, the authors tend to pay attention on family involvement in managerial position, finance authors deeply investigate the presence of family members in board, by identifying such differences with firms that engage professional outside directors. The authors with financial background focus on financial aspects and try to justify their tendencies by correlating them with the peculiarities of firms, to explicate the impact on the financial context. Therefore, ownership and governance are the most specific variables and the most suitable issues because it is easier to measure adopting financial proxy and to correlate with firms' financial aspects. Then, by examining the dimensions used to delineate financial aspects, as in the previous case, the purpose of different dimensions changes, as their level of repetition and the theory applied to explain the interaction among the investigated variables. Table 8 shows these results.

Table 8. Financial dimensions

\begin{tabular}{|c|c|c|}
\hline $\begin{array}{l}\text { Financial } \\
\text { dimensions }\end{array}$ & Financial studies sample & Management studies sample \\
\hline $\begin{array}{l}\text { Firm } \\
\text { Performance }\end{array}$ & Stock returns & Financial wealth, Financial returns \\
\hline Firm's value & $\begin{array}{l}\text { Measure of company's total value, } \\
\text { considering not only the equity market } \\
\text { capitalization }\end{array}$ & $\begin{array}{c}\text { Measure of company's total value, } \\
\text { considering not only the equity market } \\
\text { capitalization }\end{array}$ \\
\hline $\begin{array}{l}\text { Financial } \\
\text { structure }\end{array}$ & $\begin{array}{l}\text { Debt, Cash flow rights, Voting rights, } \\
\text { Control rights, Dividend policy, Share price, } \\
\text { Equity placement, Price of vote, Voting } \\
\text { price, Single/dual class stock, Liquidity, } \\
\text { Cash holding, Tunneling, Capital market }\end{array}$ & $\begin{array}{l}\text { Transaction costs, Liquidity, Asset/Capital } \\
\text { accumulation, Financial management } \\
\text { techniques, Saving capital, Debt, Equity, } \\
\text { Resource stock, Stock option, Voting } \\
\text { control, Financial interminling }\end{array}$ \\
\hline
\end{tabular}

ontrol rights, Dividend policy, Share price, Cash holding, Tunneling, Capital market

\author{
accumulation, Financial management \\ echniques, Saving capital, Debt, Equity, \\ control, Financial interminling
}


Investments

Financial

reporting

Risk

Efficiency

Resilience

Entrepreneurship

Financial market operations

Financial issues
Investor protection, Decision making, Business planning, Collateral, Diversification

Capital disclosures, Corporate disclosures, Voluntary disclosures, Corporate transparency, Corporate opacity

Risk Hedging
Investment strategy, Divestment decisions, Venture capitalists, Time horizon, Investment market, Decision making

Effort of the firm to be risk-taking

Resource allocation

Acquisitions, IPO, Merge, Transfer, Buy out, Buy-sell agreement, Estate freeze, Insider selling, Privatisation, Market reaction to news, Bid ask spread
Survival, Success, Growth, Expansion

Proactiveness, Risk taking

Acquisitions, IPO, Merge, Selling to

outsiders, Corporate venturing, Public equity market

Financial logics

Financial crisis

Financial distress, Bankrupcty

Some divergences emerge by analysing the detailed contents. The macro areas came to light from JQL sample are more articulated in the case of Financial structure and Financial market operations. The issues analysed in management journals that we did not find in financial one are resilience and entrepreneurship. On the contrary, the themes studied just by finance authors are financial reporting and financial crisis. This vision emerges also referring to the most repeated issues. Table 9 shows the most relevant themes.

Table 9. Number of articles for each financial dimension in finance and management journals

\begin{tabular}{lcc}
\hline Themes & $\begin{array}{c}\text { Financial Journals Sample } \\
\text { No. Articles }\end{array}$ & $\begin{array}{c}\text { Management Journals Sample } \\
\text { No. Articles }\end{array}$ \\
\hline Financial structure & 103 & 35 \\
Firm Performance & 71 & 74 \\
Financial market operations & 40 & 12 \\
Firm value & 33 & 6 \\
Financial reporting & 25 & - \\
Risk & - & 8 \\
Resilience & - & 16 \\
Investments & 21 & 12 \\
\hline
\end{tabular}

Not surprising, among the FJS, the first place is taken by financial structure. Firm's value takes the fourth places and it is often linked with firm's performance in the same articles. This variable takes the last place in the MJS, because the publications almost approach to this theme through a qualitative method of analysis, taking in consideration the intangible asset related to the firm's value, more than related to firm's value/performance. Some divergent themes among financial and management publications result, such as reporting, risk and resilience. The first is characteristic 
of the financial field, about the latter, it is not present among cited themes in FS sample, because its tendency is to have a more itemized approach.

\subsection{Theoretical Frameworks}

In the analysed studies, the main theory applied in the both sets is the agency theory (Jensen \& Meckling, 1976). The MJS has a more articulated theoretical framework involving various other theories, and the theoretical contribution of these publications is more relevant than practical implications. Concerning the agency theory, it is present in 13 articles regarding family involvement (Sciascia, \& Mazzola, 2008; Chrisman, Sharma, Steier, \& Chua, 2013; O'Boyle, Pollack, \& Rutherford, 2012 among others) and in 23 articles regarding firms' performance (among others Zellweger \& Nason, 2008; Martínez, Stöhr, \& Quiroga, 2007), but there is a prevalence in its adoption in the financial literature. As for FJS, it is present in 27 articles regarding the governance (among others, Hearn, 2011; Baek, Kang, \& Park, 2004; Burkart, Panunzi, \& Shleifer, 2003) and in 16 articles regarding firms' performance (among others Bertrand, Johnson, Samphantharak, \& Schoar, 2008; King, \& Santor, 2008). In both samples, it is clear that this theory is associated with specific dimensions, which contribute to define what family business means. Looking at the financial dimensions, the theory is associated with firm's performance and firm's value, because the agency costs influence the cost structure and indirectly impact on the performance and on firm's value. Furthermore, the agency relationships are one of the causes of different performance among family and non-family firms, which is the most common comparison among firms that emerges in the both journals samples. This analysis found application of the classical agency relation identified by Jensen and Meckling (1976) involving the ownership and the management, but also the application of the theory in family business (Jensen, \& Meckling, 1976). In this field, the conflict of interests regards family and nonfamily members, dominant (family) and minority (non-family) shareholders, owners and lenders, family members in different roles and conflicts arising from asymmetric altruism (Schulze, Lubatkin, Dino, \& Buchholtz, 2001). The agency cost control mechanism has a positive effect on performance, as one would expect, the increasing family involvement and utilization of control mechanisms, implies that family firms have higher agency costs than non-family firms and, thus, benefit more from the mechanism (Chrisman, Chua, \& Litz, 2004). It clearly emerges the different impact on performance and on value in family and non-family firms, which are the focus in the application of the theory in the financial field. In spite of the agency theory, in the MJS, other mentioned theories are the Behavioral theory (Cyert, \& March, 1963), Resources based view (Barney, 1981), Organizational identity theory (Albert, Ashforth, \& Dutton, 2000), Resource-dependence theory (Hillman, Withers, \& Collins, 2009), Stewardship theory (Davis, Schoorman, \& Donaldson, 1997), Optimal contracting theory (Kaplan \& Stromberg, 2003), Rent extraction theory (Choi, 2009), Stagnation theory (Steindl, 1979), Stakeholder theory (Donaldson \& Preston, 1995), Transaction costs theory (Hennart, 1988) and other organizational and finance theory, but there is not a coherent perspective through which to construct an organic overview. In this disparate scenario, it occurs to considerate a more cohesive theoretical framework, which support not only the agency perspective. The interconnection among different theories should supply academics with a wide knowledge, in order to better understand the dynamics at the basis of operational needs, by giving an effective support to practitioners. The extension of theoretical considerations let scholars to evolve the research streams, through the evaluation of a multi-dimensional scheme that takes into account requirement and purposes coming from divergent backgrounds

\section{Discussion}

This section adopts a new lens to analyze the found articles, looking at the most cited ones that allow to underline the most discussed thematic areas. Moreover, it will focus on the papers published in the last period trying to cross financial and family dimensions with the purpose to focus on the emerging gaps. In the last part, supported by the previous discussion, it will show hypothetical research directions to complete the stand knowledge and contribute to its evolution. After considering the number of citations for each journal, the study focused on papers with more than 900 citations. This approach identifies in the MJS Schulze et al., (2001) (1613 cit.), followed by Gomez-Mejía et al., (2007) (1011 cit.). From the FJS, it emerges Morck et al., 1988 (8146 cit.); Claessens et al., (2000) (5150 cit.); Anderson \& Reeb, (2003), (3400 cit.); Faccio \& Lang, (2002) (3235 cit); Villalonga \& Amit, (2004) (2378 cit); Anderson, Mansi, \& Reeb, (2003) (1245 cit); Ho \& Wong, (2001) (916 cit.). The examination of their contents let propose a schematic summary of the most debated themes in the both literature. By using a comparative approach, it is possible underling the emerging gaps between the evaluated domains. From the analysis the below conceptual scheme emerges. 


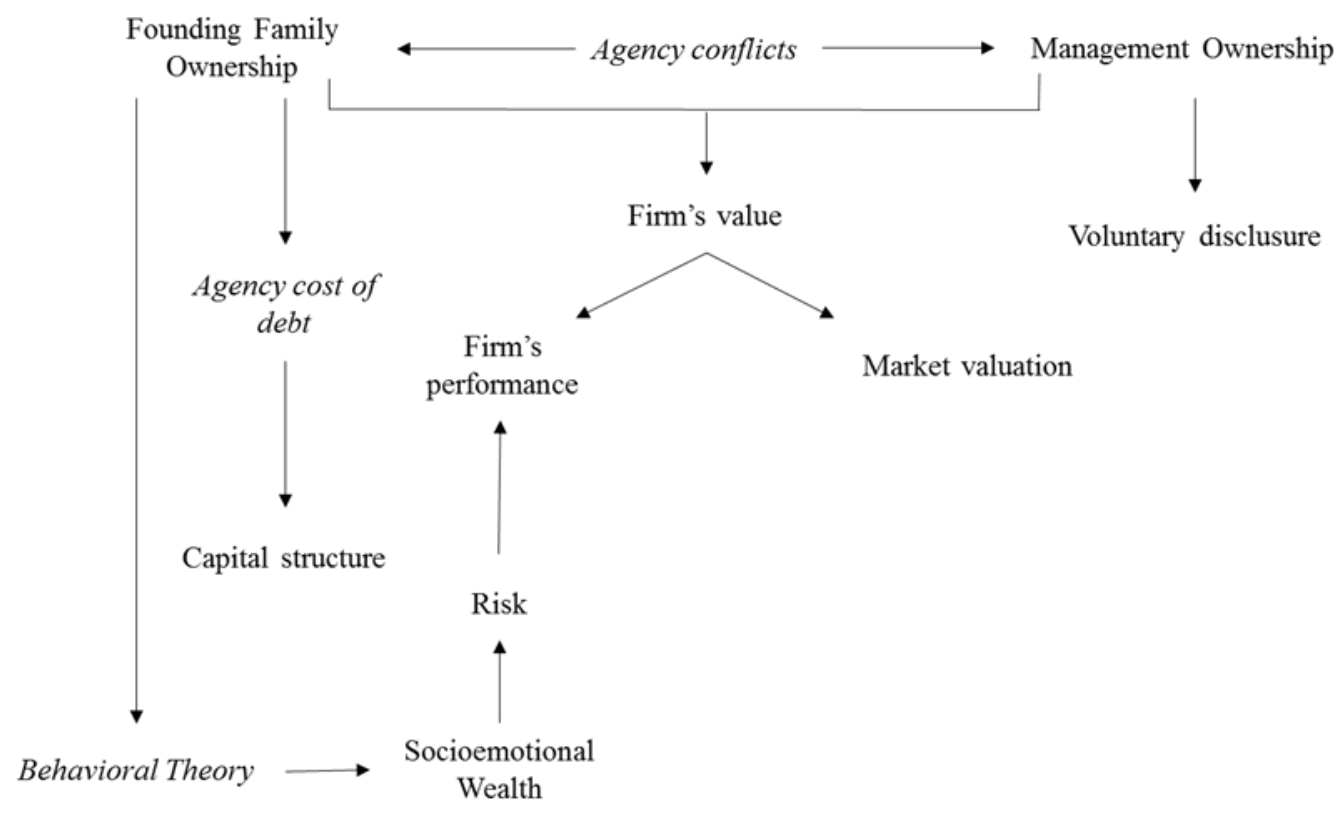

Figure 1. A synthesis of the results

This evaluation process, confirms the previous results, by highlight the main argued issues. The correlation among variables is investigated through the lens of the agency theory, by studying the hypothetical conflicts ownership/control and the impact of agency costs on firm's performance and firm's value. In family business, it need to consider intra-familial altruistic elements and clan control that supply a more cohesive purpose among stakeholders and thus there are less agency problems than in non-family firms (Chrisman et al., 2004; Daily \& Dollinger, 1992; Jensen \& Meckling, 1976). Nevertheless, some peculiar problems coming out the declination of agency conflicts in familial dynamics cannot be neglected (La Porta et al., 1999; Hendry, 2002). Moreover, owner-managers know more about the company's current earning and investment opportunities than do outside investors, for the reason it is accentuate the problem of asymmetric information (Healy \& Palepu 2001; Krishnaswami, Spindt, \& Subramaniam, 1999). Moreover, the research reveals that the impact of founding family ownership and managerial ownership on performance lead to spend some reflections on the implications for the capital structure. Anderson \& Reeb (2003) established that in general the debt costs of family businesses are lower compared with the debt costs of non-family businesses. They argued that families have a strong voice in the firm and powerful motives to steward one particular firm. The unique incentives of founding family owner-managers lead to weaken agency conflicts between the firm's debt and equity claimants and consequently benefit from lower debt costs. Focusing on the MJS, an interesting element surfaces that allow to focus on a different perspective considering performance implications in family business. It can assert that looking at firm performance specifically through the lens of risk component, family-owned firms are more risk averse than non-family firms in order not to register loss of Socioemotional Wealth. In this light, the latter result to be a relevant question that condition the financial choices, in order to preserve ownership self-interests. Owners of family firms have not the unique purpose of register high financial returns but an essential role is played by their socioemotional wealth through by adopting a conservative approach. The socioemotional wealth identifies non-financial values that could come out from different circumstances by assuming different declinations through an optic of intimate relation (Kepner, 1983), of generational succession (Handler, 1990; Casson, 1999), of social capital (Arregle, Hitt, Sirmon, \& Very, 2005), of altruism (Schulze et al., 2003) and so on. The socioemotional wealth leads to focus on some deeper consideration on how family's willing to maintain the control of a firm can influence the decision-making process, in an optic of continuity. Gomez-Mejia et al., 2007 posit that the risk taking decision is relatively conditioned to the probable loss of family control. The preservation of socioemotional set plays an essential role in evaluating implications for firm's performance. The highly-cited criteria have the limits to not show such a noteworthy articles published in the last period. For the reason the analysis followed taking into account the last 5 years of the sample, from 2010 to 2015, which is considered the maturity period of periodical distribution, in order to check for the most debated issues and to catch hypothetical gaps between the two samples. In the previous discussion, the lack of investigation in the 
financial domain of Socioemotional wealth was underlined and it persists in the recent years, even if some exception exist (among others, Gomez-Mejia, Cruz, \& Imperatore, 2014). Otherwise, by looking at articles published in management journals in the last five years, an increasing number of publications drawing on Socioemotional wealth found out (among others, Naldi, Cennamo, Corbetta, \& Gomez-Mejia, 2013, Vandemaele \& Vancauteren 2013, Minichilli, Nordqvist, Corbetta, \& Amore, 2014).

A peculiar detail emerges focusing on firm value, which publications are remarkable. Following this new path, the socioemotional wealth could contribute to determine the essential conditions that affect firm's value by considering not only quantitative aspects but also qualitative ones. Emotional considerations help to give a more complete vision on the impact of ownership and governance on firm's performance/value, by underlying the correlations between family involvement end emotional components. Family involvement is one of the main subject, but the authors link this dimension almost with the ownership, adopting a quantitative approach. Socioemotional wealth can have both positive and negative implications on firm's value and it needs to consider emotional costs and emotional returns, especially in the context of family business, in which the presence of emotional components has a substantial impact in comparison with non-family firms. Otherwise, a more integrated perspective occurs, future research could try to supply a multivariable approach because the interdependence between the socioemotional and the financial wealth must be conceptualized. Depending on the characteristics of the family business, socioemotional factors have more or less relevance than financial ones. It could be useful to conduct a comparative study, trying to understand the variables, which affect these peculiarities. The research moved forward by examining the interaction between the dimensions the most debated in the last period in the both journals' samples.

Table 10. Interaction family and financial issues in the financial journals sample

\begin{tabular}{|c|c|c|c|c|}
\hline \multicolumn{5}{|c|}{ Financial Journals Sample } \\
\hline Family dimensions & Financial dimensions & Number & Period & Theory \\
\hline $\begin{array}{c}\text { Family } \\
\text { involvement in } \\
\text { governance }\end{array}$ & \multirow{2}{*}{ Firm's performance } & \multirow{4}{*}{$10<\mathrm{N}<20$} & 2011 & Agency theory \\
\hline $\begin{array}{c}\text { Family } \\
\text { involvement in } \\
\text { ownership }\end{array}$ & & & 2012 & \\
\hline $\begin{array}{c}\text { Family } \\
\text { involvement in } \\
\text { governance }\end{array}$ & \multirow{2}{*}{ Financial structure } & & 2010/14 & \\
\hline $\begin{array}{c}\text { Family } \\
\text { involvement in } \\
\text { ownership }\end{array}$ & & & 2011 & \\
\hline Succession & Firm's Performance & \multirow{4}{*}{$5<N<10$} & 2013 & \multirow{4}{*}{ Agency theory } \\
\hline Family & Firm value & & $2012 / 14$ & \\
\hline ownership & Investments & & & \\
\hline $\begin{array}{c}\text { Family } \\
\text { involvement in } \\
\text { governance }\end{array}$ & $\begin{array}{c}\text { Financial market operation } \\
\text { Financial reporting }\end{array}$ & & 2011 & \\
\hline & interactions & $\mathrm{N}<5$ & & \\
\hline
\end{tabular}

From the financial studies, the most discussed interrelations are between family involvement in ownership/governance, and firm's performance/structure. The 2011 results to be the most proactive year, and the agency theory is the theoretical framework that rules. 
Table 11. Interaction family and financial issues in the management journals sample

\section{Management Journals Sample}

\begin{tabular}{ccccc}
\hline Family dimensions & Financial dimensions & Number & Period & Theory \\
\hline $\begin{array}{c}\text { Family involvement in } \\
\text { governance }\end{array}$ & Firm's performance & $10<\mathrm{N}<20$ & 2015 & Agency theory \\
\hline $\begin{array}{c}\text { Family involvement in } \\
\text { management }\end{array}$ & Firm's performance & $5<\mathrm{N}<10$ & 2014 \\
\hline SEW & Other interactions & $\mathrm{n}<5$ & \\
\hline Succession & &
\end{tabular}

Concerning the management field, we found out a balance among the family dimensions, but firm's performance prevails on the financial issues. In the last two years there are the majority of publications, and the agency theory is the most followed theoretical approach.

The schematic overview let reflect on the gaps that could be bridged, through a coherent advancing of financial studies in family business. The classical financial theory cannot be applied to family businesses because they are characterized by internal dynamics that should not be neglected. Through an analysis on the top Spanish family businesses, Gallo, Tàpies and Cappuyns (2004) assert the existence of a peculiar financial logic behind which personal preferences are the driving forces (Gallo, Tàpies, \& Cappuyns, 2004).

In non-family businesses, the principal aim of financial choices is to guarantee the maximization of the company's stock explicated through the market price, in order to assure the survival of firms in the long period. Focusing on family business, the continuity of the firm leads to a set of considerations beyond the financial perspective by defining the growth of firm's value considering the emotional components involved.

It could be useful to examine in depth some peculiar issues, in order to integrate the insufficient contribution present in literature (among others Amore, Minichilli, \& Corbetta, 2011; Pindado, Requejo, \& La Torre, 2015). It could be an essential means, to understand the choice concerning the financial structure and the firm's value beyond the simply consideration of performance in family business domain. The agency perspective is the most debated theoretical approach followed by academics. It concerns the examination of conflicts and costs dynamics that could be modified with the change generation, by influencing firm performance. Therefore, the integration of agency theory with emotional endowment and reputational concerns, should supply a more cohesive explanation on the contrasting relationships that could arise among firm's members by considering the most intimate reasons. The generational succession and the distinction between succession in ownership and succession in management could lead to an awareness knowledge of the drivers in the decision-making process involved in the firm's transfer, carrying influential implications to evaluate. The succession process, can threat the entrepreneurial essence typical of founder generations, for the reason it often runs parallel to the professionalization of the firms. Analysing the multi dimensions of professionalization concept (Dekker, Lybaert, Steijvers, \& Depaire, 2015) ought to be an important perspective through which investigate the impact of family commitment after succession process on financial structure, beyond the simply consideration of change in debt level. The comparison between professionalization involving family/non family members could highlight the capability to develop growth opportunities after the transition. In fact, financial choices after the succession process entail the firm's ability to create value over generations. The "familiness" as unique resource that differentiate family from their non-family counterpart (Habbershon \& Williams, 1999) evolves towards the transition process and new generations could have the opportunity to actively contribute in the increment of firm's value beyond the incomplete meaning of financial value. As Salvato and Melin, (2008) suggest, in family business the value ceation process will be characterized more by an ability to constantly reshape social interactions and meanings, than by a superior ability in accessing and 
recombining strategic resources (Salvato \& Melin, 2008). In addition, from the MS sample, the investigation of Socioemotional Wealth emerges as distinctive element because it naturally comes to light from the overlapping between the family (non-economic goals) and the business (economic interests). It could be interesting to deep examine the impact of emotional components on performance, financial structure and firm's value under a different perspective. As discussed in the previous paragraph, there is a close link between Socioemotional Wealth and the risk component in the financial choices because it could be synonymous of an essential loss. In the existing studies, the agency lens is the most used to investigate this relation, but the adoption of behavioural perspective could shed light on real reasons behind financial choices. The analysis through the behavioural theory (Cyert \& March, 1963) framework could reveal something different from the simplistic will to maintain the control in the firm and should give the opportunity to better understand the coherence among financial decisions and structural choices. The evaluation of interpersonal network through a behavioural interpretation could lead to a deeper reflection on the creating value process in family business, as real source of sustainable competitive advantage. Furthermore, this study suggests to focus on the ability of firms in implementing governance mechanisms in family business, because they result to be underestimated. The opportunity to adopt an adequate "toolkit" to manage the resources' network could mean to be strategically competitive and to build a coherence internal structure that reflects and justifies choices of financial and operational nature. Further research may improve the knowledge of how governance mechanisms in family firms contribute to align financial goals and the preservation of Socioemotional wealth by adopting non-economic motivated behaviour.

The financial implication in family business is a dynamic and complex phenomenon, and managing such diversity is a critical concern as the family network involved in the business is linked to a heterogeneous system of dynamics, which cannot be neglected. Financial aspects are declined by following the peculiarity of family business, and the inference of family variables determines a specific profile. Through the lens of management in family business, a different perspective to interpret financial studies emerges and vice versa. This review of previous research provides a novel comparative and comprehensive view of the interaction between family business and financial studies, which are inclusive of unexplored fields. The interest in exploring family business from a financial perspective has been growing and becoming increasingly rigorous. However, there are still many challenges worthy of exploration. Researchers, educators and practitioners should benefit from this paper because it deals with limits of financial studies in family business field and vice versa, where more effort is needed in addressing the complexity of the topic and to understand their peculiarities. The aim of this literature overview is to citing the prior studies to identifying new directions that integrate and advance previous research. The schematic overview on the past let scholars to focus on emerging gaps in literature and to contribute with further studies through a more aware knowledge. Moreover, the organization of literature background and the suggestions of new directions to bridge emerging gaps allow scholars to advance studies by providing implications for practitioners. The practical implications from this review reveal several sensible applications worthy of future study. Through the guidelines provided by this review, further research could represent an essential support for family business shareholders, members of their families and who wants to learn something more about the key requisite to lead business to successfully performances. In conclusion, this research, highlighting new opportunities for further research, paves the way to family business and financial scholars for future studies.

\section{References}

Albert, S., Ashforth, B.E., \& Dutton, J.E. (2000). Organizational identity and identification: Charting new waters and building new bridges. Academy of management review, 25(1), 13-17. https://doi.org/10.5465/AMR.2000.2791600

Allouche, J., Amann, B., Jaussaud, J., \& Kurashina, T. (2008). The Impact of Family Control on the Performance and Financial Characteristics of Family versus Nonfamily Businesses in Japan: A Matched-Pair Investigation. Family Business Review, 21(4), 315-329. https://doi.org/10.1177/08944865080210040104

Amore, M.D., Minichilli, A., \& Corbetta, G. (2011). How do managerial successions shape corporate financial policies in family firms?. Journal of Corporate Finance, 17(4), 1016-1027. https://doi.org/10.1016/j.jcorpfin.2011.05.002

Anderson, R.C. \& Reeb, D.M. (2003). Founding-family ownership and firm performance: evidence from the S\&P 500. The journal of finance, 58(3), 1301-1328. https://doi.org/10.1111/1540-6261.00567

Anderson, R.C., Mansi, S.A., \& Reeb, D.M. (2003). Founding family ownership and the agency cost of debt. Journal of Financial economics, 68(2), 263-285. https://doi.org/10.1016/S0304-405X(03)00067-9 
Arosa, B., Iturralde, T., \& Maseda, A. (2010). Outsiders on the board of directors and firm performance: Evidence from Spanish non-listed family firms. Journal of Family Business Strategy, 1(4), 236-245. https://doi.org/10.1016/j.jfbs.2010.10.004

Arregle, J. L., Hitt, M. A., Sirmon D., \& Very P. (2005). The development of organizational social capital and its performance implications: Insights from family firms. Unpublished manuscript. Australian Graduate School of Management, University of New South Wale.

Astrachan, J.H. \& Shanker, M.C. (2003). Family businesses' contribution to the US economy: A closer look. Family business review, 16(3), 211-219. https://doi.org/10.1177/08944865030160030601

Baek, J.S., Kang, J.K., \& Park, K.S. (2004).Corporate governance and firm value: Evidence from the Korean financial crisis. Journal of Financial economics, $71(2), \quad 265-313$. https://doi.org/10.1016/S0304-405X(03)00167-3

Barney, J. (1991). Firm resources sustained competitive advantage. Journal of Management, 17(1), 99-120. https://doi.org/10.1177/014920639101700108

Basco, R., \& Pérez Rodríguez, M. J. (2009). Studying the family enterprise holistically: Evidence for integrated family and business systems. Family Business Review, 22(1), 82-95. https://doi.org/10.1177/0894486508327824

Berrone, P., Cruz, C., Gomez-Mejia, L.R., \& Larraza-Kintana, M. (2010). Socioemotional Wealth and Corporate Responses to Institutional Pressures: Do Family-Controlled Firms Pollute Less?. Administrative Science Quarterly, 55(1), 82-113. https://doi.org/10.2189/asqu.2010.55.1.82

Bertrand, M., Johnson, S., Samphantharak, K., \& Schoar, A. (2008). Mixing family with business: A study of Thai business groups and the families behind them. Journal of financial Economics, 88(3), 466-498. https://doi.org/10.1016/j.jfineco.2008.04.002

Brenes, E.R., Madrigal, K., \& Requena, B. (2011). Corporate governance and family business performance. Journal of Business Research, 64(3), 280-285. https://doi.org/10.1016/j.jbusres.2009.11.013

Burkart, M., Panunzi, F., \& Shleifer, A. (2003). Family firms. The Journal of Finance, 58(5), 2167-2202. https://doi.org/10.1111/1540-6261.00601

Casson, M. (1999). The economics of the family firm. Scandinavian Economic History Review, 17(1), 10-23. https://doi.org/10.1080/03585522.1999.10419802

Choi, A.H. (2009). A rent extraction theory of right of first refusal. The Journal of Industrial Economics, 57(2), 252-262. https://doi.org/10.1111/j.1467-6451.2009.00377.x

Chrisman, J.J., Chua, J.H., \& Litz, R.A. (2004). Comparing the agency costs of family and non-family firms Conceptual issues and exploratory evidence. Entrepreneurship Theory and practice, 28(4), 335-354. https://doi.org/10.1111/j.1540-6520.2004.00049.x

Chrisman, J.J., Chua, J.H., Kellermanns, F.W., Matherne III, C.F., \& Debicki, B.J. (2008). Management journals as venues for publication of family business research. Entrepreneurship Theory and Practice, 32(5), 927-934. https://doi.org/10.1111/j.1540-6520.2008.00263.x

Chrisman, J.J., Sharma, P., Steier, L.P., \& Chua, J.H. (2013). The influence of family goals, governance, and resources on firm outcomes. Entrepreneurship Theory and Practice, 37(6), 1249-1261. https://doi.org/10.1111/etap.12064

Chua, J.H., Chrisman, J.J., \& Bergiel, E.B. (2009). An agency theoretic analysis of the professionalized family firm. Entrepreneurship Theory and Practice, 33(2), 355-372. https://doi.org/10.1111/j.1540-6520.2009.00294.x

Claessens, S., Djankov, S., \& Lang, L. H. (2000). The separation of ownership and control in East Asian corporations. Journal of financial Economics, 58(1), 81-112. https://doi.org/10.1016/S0304-405X(00)00067-2

Corbetta, G. \& Salvato, C. (2004). Self-serving or self-actualizing? Models of man and agency costs in different types of family firms: A commentary on "comparing the agency costs of family and non-family firms: Conceptual issues and exploratory evidence. Entrepreneurship Theory and Practice, 28(4), 355-362. https://doi.org/10.1111/j.1540-6520.2004.00050.x

Cyert, R. M., \& March, J. G. (1963). A Behavioral Theory of the Firm. In John Miner B. (Ed.), Organizational Behavior 2: Essential theories of process and structure (pp. 60-77). Prentice-Hall, Englewood Cliffs, NJ.

Daily, M., \& Dollinger, M.J. (1992). An empirical examination of ownership structure in family and professionally 
managed firms. Family Business Review, 5(2), 117-36. https://doi.org/10.1111/j.1741-6248.1992.00117.x

Davis, J.H., Schoorman, F.D., \& Donaldson L. (1997). Towards a Stewardship Theory of Management. Academy of Management Review, 22(1), 20-47. https://doi.org/10.2307/259223

Dekker, J., Lybaert, N., Steijvers, T., \& Depaire, B. (2015). The effect of family business professionalization as a multidimensional construct on firm performance. Journal of Small Business Management, 53(2), 516-538. https://doi.org/10.1111/jsbm.12082

Di Giuli, A., Caselli, S., \& Gatti, S. (2011). Are small family firms financially sophisticated?. Journal of Banking \& Finance, 35(11), 2931-2944. https://doi.org/10.1016/j.jbankfin.2011.03.021

Donaldson, T., \& Preston, L. E. (1995). The stakeholder theory of the corporation: Concepts, evidence, and implications. Academy of management Review, 20(1), 65-91. https://doi.org/10.2307/258887

Dreux IV, D. R. (1990). Financing family business: Alternatives to selling out or going public. Family Business Review, 3(3), 225-243. https://doi.org/10.1111/j.1741-6248.1990.00225.x

Dyer, W. G. (2006). Examining the "family effect" on firm performance. Family business review, 19(4), 253-273. https://doi.org/10.1111/j.1741-6248.2006.00074.x

Faccio, M., \& Lang, L. H. (2002). The ultimate ownership of Western European corporations. Journal of financial economics, 65(3), 365-395. https://doi.org/10.1016/S0304-405X(02)00146-0

Franks, J., Mayer, C., Volpin, P., \& Wagner, H. F. (2012). The life cycle of family ownership: International evidence. The Review of Financial Studies, 25(6), 1675-1712. https://doi.org/10.1093/rfs/hhr135

Gallo, M. Á., Tàpies, J., \& Cappuyns, K. (2004). Comparison of family and nonfamily business: Financial logic and $\begin{array}{lllll}\text { personal preferences. } & \text { Family }\end{array}$ https://doi.org/10.1111/j.1741-6248.2004.00020.x

Gisser, M.V., \& Gonzalez, E.E. (1993). Family businesses: A breed apart in crafting deals. Merger \& Acquisitions, 27(8), 39-44.

Gomez-Mejia, L. R., Cruz, C., Berrone, P., \& De Castro, J. (2011). The bind that ties: Socioemotional wealth preservation in family firms. The academy of management annals, 5(1), 653-707. https://doi.org/10.1080/19416520.2011.593320

Gómez-Mejía, L. R., Haynes, K. T., Núñez-Nickel, M., Jacobson, K. J., \& Moyano-Fuentes, J. (2007). Socioemotional wealth and business risks in family-controlled firms: Evidence from Spanish olive oil mills. Administrative science quarterly, 52(1), 106-137. https://doi.org/10.2189/asqu.52.1.106

Gomez-Mejia, L., Cruz, C., \& Imperatore, C. (2014). Financial reporting and the protection of socioemotional wealth in family-controlled firms. European Accounting Review, 23(3), 387-402. https://doi.org/10.1080/09638180.2014.944420

Habbershon, T. G., \& Williams, M. L. (1999). A resource-based framework for assessing the strategic advantages of family firms. Family Business Review, 12(1), 1-25. https://doi.org/10.1111/j.1741-6248.1999.00001.x

Habbershon, T. G., Williams, M., \& MacMillan, I. C. (2003). A unified systems perspective of family firm performance. Journal of business venturing, 18(4), 451-465. https://doi.org/10.1016/S0883-9026(03)00053-3

Handler, W.C. (1990). Succession in family firms: A mutual role adjustment between entrepreneur and next generation family members. Entrepreneurship: Theory and Practice, 15(1), 37-51.

Healy, P. M., \& Palepu, K. G. (2001). Information asymmetry, corporate disclosure, and the capital markets: A review of the empirical disclosure literature. Journal of accounting and economics, 31(1), 405-440. https://doi.org/10.1016/S0165-4101(01)00018-0

Hearn, B. (2011). The performance and the effects of family control in North African IPOs. International Review of Financial Analysis, 20(3), 140-151.

Hendry, J. (2002). The principal's other problems: Honest incompetence and the specification of objectives. Academy of management review, 27(1), 98-113. https://doi.org/10.1016/j.irfa.2011.02.006

Hennart, J. F. (1988). A transaction costs theory of equity joint ventures. Strategic management journal, 9(4), 361-374. https://doi.org/10.1002/smj.4250090406

Hillman, A.J., Withers, M.C., \& Collins, B.J. (2009). Resource dependence theory: A review. Journal of management, 
35(6). https://doi.org/10.1177/0149206309343469

Ho, S. S., \& Wong, K. S. (2001). A study of the relationship between corporate governance structures and the extent of voluntary disclosure. Journal of International Accounting, Auditing and Taxation, 10(2), 139-156. https://doi.org/10.1016/S1061-9518(01)00041-6

Hollander, B. S., \& Elman, N. S. (1988). Family-owned businesses: An emerging field of inquiry. Family business review, I(2), 145-164. https://doi.org/10.1111/j.1741-6248.1988.00145.x

Jensen, M. C., \& Meckling, W. H. (1976). Theory of the firm: Managerial behavior, agency costs and ownership structure. Journal of financial economics, 3(4), 305-360. https://doi.org/10.1016/0304-405X(76)90026-X

Kaplan, S. N., \& Strömberg, P. (2003). Financial contracting theory meets the real world: An empirical analysis of venture capital contracts. The Review of Economic Studies, 70(2), 281-315. https://doi.org/10.1111/1467-937X.00245

Kepner, E. (1983). The family and the firm: A co-evolutionary perspective. Organizational Dynamics, 12(1), 57-70. https://doi.org/10.1016/0090-2616(83)90027-X

Kim, Y., \& Gao, F. Y. (2013). Does family involvement increase business performance? Family-longevity goals' moderating role in Chinese family firms. Journal of Business Research, 66(2), 265-274. https://doi.org/10.1016/j.jbusres.2012.08.018

King, M. R., \& Santor, E. (2008). Family values: Ownership structure, performance and capital structure of Canadian firms. Journal of Banking \& Finance, 32(11), 2423-2432. https://doi.org/10.1016/j.jbankfin.2008.02.002

Koropp, C., Grichnik, D., \& Kellermanns, F. (2013). Financial attitudes in family firms: The moderating role of family commitment. Journal of Small Business Management, 51(1), 114-137. https://doi.org/10.1111/j.1540-627X.2012.00380.x

Krishnaswami, S., Spindt, P. A., \& Subramaniam, V. (1999). Information asymmetry, monitoring, and the placement structure of corporate debt. Journal of Financial Economics, 51(3), 407-434. https://doi.org/10.1016/S0304-405X(98)00059-2

Mahérault, L. (2004). Is there Any Specific Equity Route for Small and Medium-Sized Family Businesses? The French Experience. Family Business Review, 17(3), 221-235. https://doi.org/10.1111/j.1741-6248.2004.00015.x

Martínez, J. I., Stöhr, B. S., \& Quiroga, B. F. (2007). Family ownership and firm performance: Evidence from public companies in Chile. Family Business Review, 20(2), 83-94. https://doi.org/10.1111/j.1741-6248.2007.00087.x

Mazzola, P., Sciascia, S., \& Kellermanns, F. W. (2013). Non-linear effects of family sources of power on performance. Journal of Business Research, 66(4), 568-574. https://doi.org/10.1016/j.jbusres.2012.01.005

Miller, D., \& Breton-Miller, L. (2006). Family governance and firm performance: Agency, stewardship, and capabilities. Family business review, 19(1), 73-87. https://doi.org/10.1111/j.1741-6248.2006.00063.x

Milston, M.J. \& Cohn, T. (1967). Personal and Business Aspects of Stockholder Agreements. Journal of accountancy, 124(4), 41-45.

Minichilli, A., Nordqvist, M., Corbetta, G., \& Amore, M. D. (2014). CEO succession mechanisms, organizational context, and performance: A socio-emotional wealth perspective on family-controlled firms. Journal of Management Studies, 51(7), 1153-1179. https://doi.org/10.1111/joms.12095

Morck, R., Shleifer, A., \& Vishny, R. W. (1988). Management ownership and market valuation: An empirical analysis. Journal of financial economics, 20, 293-315. https://doi.org/10.1016/0304-405X(88)90048-7

Mustakallio, M., Autio, E., \& Zahra, S. A. (2002). Relational and contractual governance in family firms: Effects on strategic decision making. Family business review, 15(3), 205-222. https://doi.org/10.1111/j.1741-6248.2002.00205.x

Naldi, L., Cennamo, C., Corbetta, G., \& Gomez-Mejia, L. (2013). Preserving socioemotional wealth in family firms: Asset or liability? The moderating role of business context. Entrepreneurship Theory and Practice, 37(6), 1341-1360. https://doi.org/10.1111/etap.12069

O'Boyle, E. H., Pollack, J. M., \& Rutherford, M. W. (2012). Exploring the relation between family involvement and firms' financial performance: A meta-analysis of main and moderator effects. Journal of Business Venturing, 27(1), 1-18. https://doi.org/10.1016/j.jbusvent.2011.09.002 
Olson, P. D., Zuiker, V. S., Danes, S. M., Stafford, K., Heck, R. K., \& Duncan, K. A. (2003). The impact of the family and the business on family business sustainability. Journal of business venturing, 18(5), 639-666. https://doi.org/10.1016/S0883-9026(03)00014-4

Pindado, J., Requejo, I., \& la Torre, C. (2015). Does family control shape corporate capital structure? An empirical analysis of eurozone firms. Journal of Business Finance \& Accounting, 42(7-8), 965-1006. https://doi.org/10.1111/jbfa.12124

Porta, R., Lopez-de-Silanes, F., \& Shleifer, A. (1999). Corporate ownership around the world. The journal of finance, 54(2), 471-517. https://doi.org/10.1111/0022-1082.00115

Praet, A. (2013). Family firms and the divestment decision: An agency perspective. Journal of Family Business Strategy, 4(1), 34-41. https://doi.org/10.1016/j.jfbs.2012.12.002

Salvato, C., \& Melin, L. (2008). Creating value across generations in Family-Controlled businesses: The role of family social capital. Family Business Review, 21(3), 259-276. https://doi.org/10.1177/08944865080210030107

Schulze, W. S., Lubatkin, M. H., \& Dino, R. N. (2003). Toward a theory of agency and altruism in family firms. Journal of business venturing, 18(4), 473-490. https://doi.org/10.1016/S0883-9026(03)00054-5

Schulze, W. S., Lubatkin, M. H., Dino, R. N., \& Buchholtz, A. K. (2001). Agency relationships in family firms: Theory and evidence. Organization science, 12(2), 99-116. https://doi.org/10.1287/orsc.12.2.99.10114

Sciascia, S., \& Mazzola, P. (2008). Family involvement in ownership and management: Exploring nonlinear effects on performance. Family Business Review, 21(4), 331-345. https://doi.org/10.1177/08944865080210040105

Stafford, K., Duncan, K. A., Dane, S., \& Winter, M. (1999). A research model of sustainable family businesses. Family Business Review, 12(3), 197-208. https://doi.org/10.1111/j.1741-6248.1999.00197.x

Steen, A., \& Welch, L. S. (2006). Dancing with giants: Acquisition and survival of the family firm. Family Business Review, 19(4), 289-300. https://doi.org/10.1111/j.1741-6248.2006.00076.x

Steier, L. (2001). Family firms, plural forms of governance, and the evolving role of trust. Family Business Review, 14(4), 353-368. https://doi.org/10.1111/j.1741-6248.2001.00353.x

Steindl, J. (1979). Stagnation theory and stagnation policy. Cambridge Journal of Economics, 3(1), 1-14.

Swartz, S., (1989). The challenges of multidisciplinary consulting to family-owned businesses. Family Business Review, 2(4), 329-339. https://doi.org/10.1111/j.1741-6248.1989.tb00002.x

Tranfield, D., Denyer, D., \& Smart, P. (2003). Towards a methodology for developing evidence-informed management knowledge by means of systematic review. British journal of management, 14(3), 207-222. https://doi.org/10.1111/1467-8551.00375

Vandemaele, S., \& Vancauteren, M. (2015). Nonfinancial goals, governance, and dividend payout in private family firms. Journal of Small Business Management, 53(1), 166-182. https://doi.org/10.1111/jsbm.12063

Villalonga, B., \& Amit, R. (2006). How do family ownership, control and management affect firm value?. Journal of financial Economics, 80(2), 385-417. https://doi.org/10.1016/j.jfineco.2004.12.005

Voordeckers, W., Le Breton-Miller, I., Miller, D., Jain, B. A., Shao, Y. (2014). In Search of the Best of Both Worlds: Crafting a Finance Paper for the Family Business Review 281. Family Business Review, 27(4), 281-286. https://doi.org/10.1177/0894486514552175

Zahra, S.A. (2005). Entrepreneurial risk taking in family firms. Family Business Review, 18(1), 23-40. https://doi.org/10.1111/j.1741-6248.2005.00028.x

Zellweger, T.M., \& Nason, R.S. (2008). A stakeholder perspective on family firm performance, Family Business Review, 21(3), 203-216. https://doi.org/10.1177/089448665080210030103 